\title{
CONTRIBUTION OF AGRICULTURE TO THE DEVELOPMENT OF SERBIA
}

\author{
Slavka Mitrović ${ }^{1}$, Aleksandra Mitrović2 ${ }^{2}$ Maja Cogoljevićc
}

\begin{abstract}
Summary
The Republic of Serbia has significant resources for the development of agriculture (natural, scientific and professional). However, agriculture doesn't achieve the results adequate to conditions it has and which are expected of it. The aim of the research in this paper is to perceive the contribution of agriculture in the development of Serbia. The contribution of agriculture was considered by an analysis of next indicators: 1 . Share of rural population in total population and an active rural population in the total work force, 2. Share of agriculture in the creation of gross domestic product (GDP) and, 3. Contribution of agriculture and agro-industry to the foreign trade exchange. The analysis of the mentioned indicators points out that our developmental strategy must be based on the increase of agricultural-food products export (intensive production), and the change in production structure in accordance with the solvent demand (especially for the demand of ecologically healthy food) and which level of finalization would be higher, in order to increase competitiveness and a new value. In this paper were used published data of the Statistical Office of the Republic of Serbia, and then the research results of some authors in this field, as well as the results of the authors' other research. The research period was from the year 2000 to the year 2015. In the analysis of contribution (performances) of agriculture were used the system and comparative analysis, as well as the standard statistical - mathematical instrumentation: average values, a rate of change and a coefficient of determination. In the paper were presented also the linear trends of GDP and income of agriculture and a share of agriculture in GDP, as well as the export/import of whole economy and agriculture trends.
\end{abstract}

Key words: agriculture, rural population, gross domestic product (GDP), foreign trade exchange, competitiveness.

JEL: Q10, Q13, Q18

1 Slavka Mitrović Ph.D., Assistant, University in Pristina, Faculty of Agriculture, 38219 Lešak, Phone: +381 2888 261, E-mail: slavka.mitrovic@pr.ac.rs

2 Aleksandra Mitrović M.Sc., Professor, Forest High School of Kraljevo, Karadjordjeva Square no. 262, 36000 Kraljevo, Phone: +381 36352 235, E-mail: aleksandramitrovic754@gmail.com

3 Maja Cogoljević Ph.D., Assistant Professor, Faculty of Business Economics and Entrepreneurship, Vojvode Vlahovića Street no. 35b, Belgrade, Serbia, Phone: +381 6310211 28, E-mail: maja. cogoljevic@vspep.edu.rs

EP 2017 (64) 2 (805-819) 


\section{Introduction}

Agriculture, as a production economic activity, is a part of overall economic system, and therefore the status of agriculture reflects also on the economic system, i.e. the whole economy. In that sense, the position and contribution of agriculture come from its interdependence of other activities in rural areas, and especially its importance for keeping numerous populations, the preservation of ecological balance and environmental protection.

In perceiving a role and contribution of agriculture, the following indicators use in economic development ${ }^{4}:$ 1) share of agricultural population in the total population and the active rural population in the whole work force, 2) share of agriculture in the creation of gross domestic product, 3) contribution of agriculture in the foreign trade exchange.

Lessons learnt on the aforementioned indicators in the field of agriculture in the world "refer to the conclusion that the relative significance of agriculture in economic and social structure of every national economy decreases with the increase in the level of total social-economic development” (Milanović, 2002). That is to say, ,as an income of some country is higher, the significance of agricultural contribution to the creation of this income is lower" (Stipetić, 1987). Nevertheless, „at the same time, it doesn't mean that absolutely speaking, agriculture in high developed countries is less developed than in underdeveloped countries, but on the contrary, a phenomenon that agriculture in under developed countries is backward and low-productive and as such is a basic cause that these countries are captured in, as often stated as "the magical circle of poverty“ (Maksimović et al., 2013).

As various types of products, i.e. the material goods manufacture in agriculture, it belongs to a group of primary activities (it takes work items directly from nature). Likewise, agriculture is a key (strategic) economic activity, because it produces food, and it is well known that only those countries which have their own food production can achieve the economic, social and political stability.

Although agriculture is the oldest economic activity of material production, it isn't still the most developed. On the contrary, it is relatively lagging behind in almost all countries. The reason lies primarily in the fact that this economic branch is by its nature less productive in regard to other economic branches, first of all, in regard to industry, so there is a lower level of development of productive forces. Nonetheless, agriculture is a specific economic branch, which results in a lower income, and thereby also a lower life standard of its population. In the text below, we will perceive the contribution of agriculture in Serbian development through these three indicators.

\section{Aim of the paper and the used methodology}

4 Contribution of agriculture to the economic development of one national economy can be analysed also through the proportion of investments in agriculture in total economic investments, as well as the share of expenditures for food in total expenditures for the personal consumption of a household. 
The goal of this paper is to determine the previous contribution of agriculture in Serbian development and search a solution for its growth and improvement, while it doesn't realise any results adequate to conditions it has and which are expected of it.

The analysis, which aims to evaluate the contribution of agriculture, is based on the relevant data from the subjected analysis. It is evident from tables in this paper that the most of data was taken over from the unique database of the SORS (SORS electronic database). Surely that graphs represent a derivative that the authors have prepared based on the original SORS data.

The goal of studying the contribution of agriculture in the development of Serbia has been realised by the use of system and comparative analysis, as well as by using the statistical and mathematical instrumentation, such as: average values, rates of change and a coefficient of determination. There was also considered the linear trends of GDP, as well as the trends of export/import of the total economy and agriculture.

\section{Research results}

\section{Share of rural population in total population and the active rural population in total work force}

The process of deagrarization of rural population in Serbia was developing dynamically. The economic development concept has an effect on it. Namely, an imperative was the development of industry, which will further develop the other sectors of economy. Hence, the structural changes in economy were causing also the structural changes in population. In that way, the share of rural population in total population was decreased from $72.3 \%$ in 1948 to $16.7 \%$ in 1991 , i.e. from $10.9 \%$ in 2002 to $6.8 \%$ in 2011 . Likewise, the rural population was decreased for more than 488 thousands inhabitants (from 1.305 thousands to 817 thousands) in the period between the two censuses, in the year 1991 and 2002, i.e. 326 thousands (from 817 thousands to 491 thousands) in the period between the two censuses, in 2002 and 2011. In the period from 1991 to 2002, the total population was intensively decreasing by an average annual rate of $-4.2 \%$ (from 7.822 thousands to 7.498 thousands), as in the period from 2002 to 2011 by the average annual rate of $-4.1 \%$ (from 7.498 thousands inhabitants to 7.186 thousands inhabitants) (SORS, 2017). It is evident that in the same period (Graph 1) the active population was decreasing, so the share of active rural population in the total rural population was decreased for $4.5 \%$, i.e. $9.6 \%$, but it still is relatively high, even in comparison with ex-Yu countries, i.e. the surrounding countries.

Besides, in the same period (from 1991 to 2002) was decreased the share of active rural population in the total rural population of Serbia for $9.4 \%$. Likewise, in the period between the two censuses, in 2002 and 2011, the share of active rural population in the total active population was decreased for $6.5 \%$. The share of rural population in total population was decreased for $5.8 \%$, i.e. $4.1 \%$. 
Graph 1. Structure of population by activities

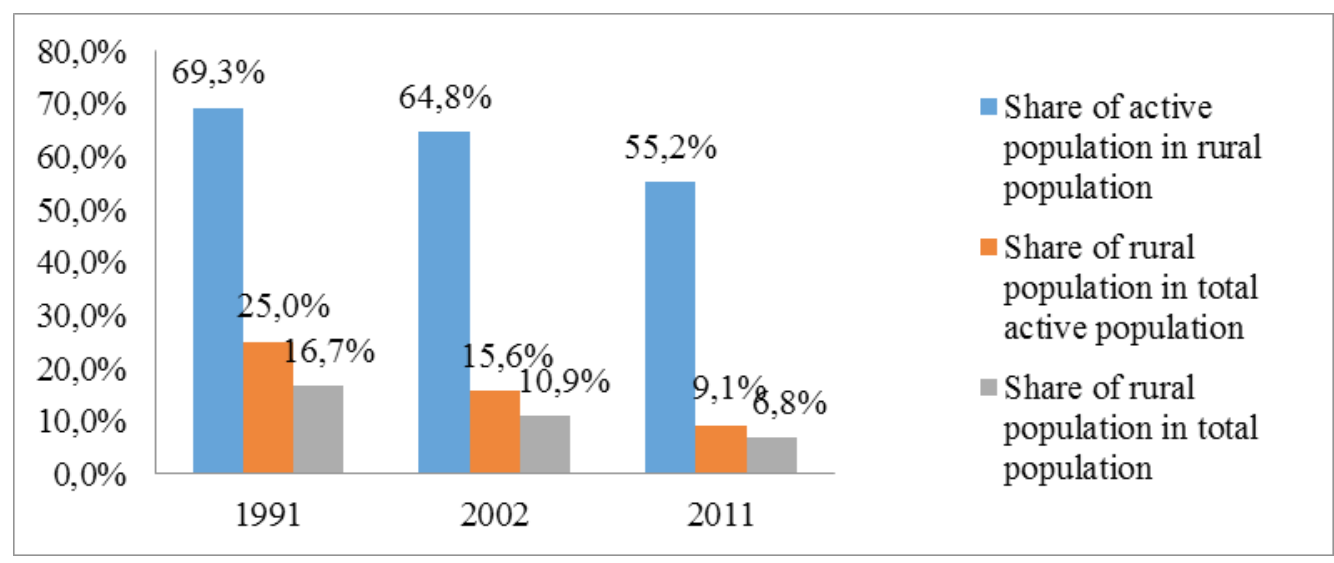

Sourse: Autor's calculation based on data from the Statistical Office of the Republic Of Serbia, Belgrade, Electronic databases, February, 2017.

If we would perceive the population categories according to activities (Graph 2), then we could say that the active rural population in regard to the total population in the period 1991-2002 was decreased for $4.5 \%$, i.e. $3.3 \%$ in the period from 2002 to 2011 . In the same period was noticed the decrease in share of the supported rural population for $1.3 \%$, i.e. $0.7 \%$. As opposed to the decrease in active and supported rural population, we can see the increase in the active non-rural population for $3.5 \%$, and was notices the decrease for $0.7 \%$. The share of supported non-rural population in the total population for the same period was increased for $2.2 \%$, i.e. for $4.8 \%$ (Mitrović, 2016 a).

Graph 2. Categories of population, according to activities, by censuses

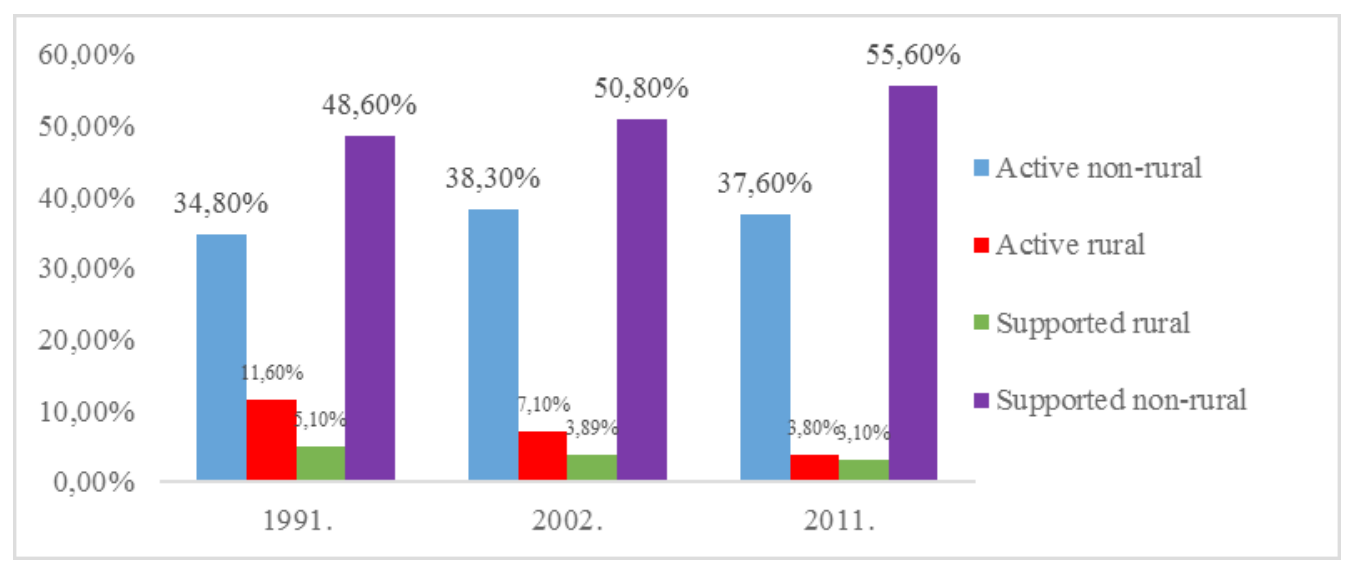

Sourse: Autor's calculation according to data from the Statistical Office of the Republic Of Serbia, Belgrade, Electronic databases, February, 2017

Although a decreasing trend of number of population in rural areas is permanent, the potentials for development of agriculture and rural development in Serbia remain 808 
at high level. That is to say, ,the working rural population in comparison with the urban population has higher rates of activity and employment and the lower rates of unemployment and inactivity“(MAEP, 2014). However, if we observe only a number of rural populations, it is not a sufficient indicator about the supply of agriculture with work force. That is to say, Serbia has a poor age structure of work force in agriculture. The analysis of age structure of holding holders points out that the share of holding holders older than 50 years of age in 2002 was $44.32 \%$, and in 2012 was increased to $63.2 \%$. Hence, it is often spoken about the labour problem in agriculture, although a number of workers in this field aren't a limiting factor for its development. If it is about the labour structure on family households in 2012, there should say that most of labour is family members or relatives $(56.3 \%)$. It points out to significant amount of informal labour, which is engaged in agriculture within family holdings, and with the support of kinsmen work force (Praća et al., 2017). As it is about the share of holding holders in the total work force, it is $43.6 \%$, and the share of permanently employed persons on family holdings is very small and amounts only 1.785 persons or $0.1 \%$ (Bogdanov, Babović, 2014).

There should be pointed out that in the European Union, a primary sector participates with around $6 \%$ in the total employment. Situation in surroundings shows significant differences. In this way, the primary sector in Croatia participates in employment with $13.2 \%$, in Macedonia 18.2\%, in Bosnia and Herzegovina 20.6\%, in Serbia (without Kosovo and Metohija) 21.4\%, Montenegro 28\% and Albania 57\%. In fact, the share of agriculture in employment in Serbia (without Kosovo) is over 20\%,,which are 6.5 times more than the share of agriculture in Czech Republic and Slovakia. High share can be found in Romania - 30\%, Bulgaria - 19.2\%, and Poland - $12 \%$ " (Savić et al., 2016). It means that ,the share of agriculture in the total employment in Serbia is still relatively high. In agriculture works $21.4 \%$ of employees, or around $18 \%$ of active population"(Cvijanović et al., 2013a). This high share of agriculture in employment is substantially the consequence ,of deindustrialisation of economy and the decline of industry, besides the historical heritage and natural conditions"(Savić et al., 2016). Likewise, a high share of agriculture in the total employment is a result of low inflow of the foreign direct investments (FDI) in comparison with other sectors. Besides ,agriculture could achieve a potentially high level of development, as well as a level of countries it could compare with on the world market, if the level of investments would be proportionated to a level of contribution of agriculture to GDP“ (Pejanović, 2008).

There should be emphasized that the reproductive power of agricultural holdings as the organizational-production units has been seriously endangered, even in the most intensive agricultural area (Vojvodina). In that context speaks the census in 2012. That is to say, around 433.399 holdings have one or two members. The survival of around $68 \%$ of holdings as the production units brings into question. Data show that households which are engaged in agriculture are decreasing from 970 thousands in the year 1991 to 779 thousands in 2002, while in the year 2012 it was decreased to 631.552, or around $20 \%$ (SORS, 2013). Taking into consideration all mentioned facts, we can 
conclude that an average size of family agricultural holdings is 4.50 hectares. Anyhow, a number of holdings of size up to 2.00 ha and from 2.01 ha to 5.00 ha is 480.775 $(298286+182489)$, or $77 \%$ in regard to the total number of agricultural holdings. We must say that holdings up to 2 ha participate with $47 \%$ in regard to the total number of holdings. The least holdings possess from 50 to 100 ha $(0.7 \%)$ and over 100 ha $(0.2 \%)$. Thus, the Serbian agriculture is based on small family holdings with low labour productivity and small surpluses in production.

When it comes to the surrounding countries, in the structure of land fund of the current EU members prevail small properties up to 3 ha, or over $60 \%$ of agricultural holdings. In these countries, the most of holdings (no more than 5 ha) have Bulgaria $96.8 \%$, Romania $93.8 \%$, Greece $76.1 \%$. Holdings with the property from 5 to 10 ha are negligible. In the region, Bosnia and Herzegovina and Greece have holdings with the property of over 10 ha, or about $5 \%$ in regard to the total number of holdings (Stevanović, Đorović, 2009).

\section{The share of agriculture in the creation of gross domestic product (GDP)}

Contrary to numerous influences that could blur the tendencies of development, there can be although concluded that the share of agriculture decreases (a regular phenomenon) in the final product of the nation, i.e. GDP. In other words, when it is about agriculture in Serbia, there should be emphasized that after the Second World War, it had a significant share in the creation of GDP. However, in the period 1955-1985 its share had significantly decreased (from $41 \%$ to $17 \%$ ), as a result of the economic development (industrialisation) of our country. The period from 1986 to 1990 is a phase of complete relative stagnation of agriculture, i.e. the agro-complex in the total economic structure (Milanović, 2002). In the beginning of twenties, the share of agriculture in GDP was amounted around 15.4\%. However, in the year 1995 has come to the increase in agricultural share and has amounted $22.5 \%$ of GDP (Tomić et al., 2002).

Due to the economic sanctions that were imposed to SRY, i.e. Serbia by the UN Security Council, there was come to disturbance in the economy, and therefore in 2002 in regard to 1995 was halved the GDP (gross domestic products). Nevertheless, the GDP in the period 2000-2015 had a positive growth rate of $16.4 \%$ (Table 1). In the same period was decreased the share of agriculture in GDP from $18.3 \%$ to $6.8 \%$. Decline in the share of agriculture in GDP is not only a result of a regular phenomenon, but also an economic crisis, while besides this decrease in the share of agriculture in GDP, the Serbian economy isn't developed, regarding that other economic activities record a low economic activity (Mitrović, 2016b).

There should say that an average value of the share of agriculture in GDP of Serbia in the period 2006-2015 was amounted 8.20\%, which was significantly below the European average. In the Republic of Serbia there is a disproportionate ration between a number of rural populations and their share in the creation of GDP, unlike the EU countries. Only $5 \%$ of the EU rural population participates with $15 \%$ in GDP of the Union, while in Serbia a larger number of rural populations takes part in the creation of GDP lower 
value, i.e. around $7 \%$ of rural population participates in the creation of over $8 \%$ of GDP. „Although there is the decrease in the share of GDP in this sector, it significantly contributes to other industrial sectors of Serbian economy, which depend directly from the raw material in agriculture, and then the input industry for agriculture, as well as the supporting service activities“" (Cvijanović et al., 2013 a). Agriculture, i.e. agro-industry, together with other sectors of economy, more precisely manufacturers and processors of inputs and raw material exceeds $40 \%$ of GDP by its share (CEP 2017). This leads to the conclusion that Serbia is an agrarian country.

Table 1. Share of agriculture and food products, beverages and tobacco in GDP of the Republic of Serbia, $2000-2015$

millions RSD

\begin{tabular}{|c|c|c|c|c|c|}
\hline \multirow[b]{2}{*}{ Year } & \multirow{2}{*}{$\begin{array}{c}\text { GDP } \\
\text { Value }\end{array}$} & \multicolumn{2}{|c|}{ Agriculture } & \multicolumn{2}{|c|}{$\begin{array}{c}\text { Manufacture of food } \\
\text { products, beverages and } \\
\text { tobacco }\end{array}$} \\
\hline & & Value & $\begin{array}{c}\text { Share in GDP } \\
(\%)\end{array}$ & Value & $\begin{array}{c}\text { Share in GDP } \\
(\%)\end{array}$ \\
\hline 2000 & $413,120.6$ & $75,783.7$ & 18.3 & $27,857.0$ & 6.7 \\
\hline 2001 & $820,842.1$ & $146,278.2$ & 17.8 & $52,750.6$ & 6.4 \\
\hline 2002 & $1,037897.3$ & $133,958.9$ & 12.9 & $59,769.6$ & 5.7 \\
\hline 2003 & $1,220160.0$ & $138,900.5$ & 11.4 & $65,901.8$ & 5.5 \\
\hline 2004 & $1,451448.2$ & $170,182.9$ & 11.7 & $69,109.7$ & 4.7 \\
\hline 2005 & $1,751371.2$ & $174,757.6$ & 10.0 & $77,473.6$ & 4.4 \\
\hline 2006 & $2,055198.1$ & $195,234.1$ & 9.5 & $83,056.9$ & 4.1 \\
\hline 2007 & $2,355065.6$ & $195,055.4$ & 8.3 & $99,669.6$ & 4.3 \\
\hline 2008 & $2,744913.2$ & $238,477.5$ & 8.7 & $117,005.2$ & 4.2 \\
\hline 2009 & $2,880059.0$ & $231,680.4$ & 8.0 & $127,687.4$ & 4.4 \\
\hline 2010 & $3,067210.2$ & $261,510.4$ & 8.5 & $125,575.9$ & 4.2 \\
\hline 2011 & $3,407563.2$ & $306,607.7$ & 9.0 & $140,798.6$ & 4.1 \\
\hline 2012 & $3,584235.8$ & $269,999.8$ & 7.5 & $151,644.5$ & 4.3 \\
\hline 2013 & $3,876403.4$ & $305,519.7$ & 7.9 & $167,182.7$ & 4.4 \\
\hline 2014 & $3,908469.6$ & $302,226.3$ & 7.7 & $162,508.6$ & 4.2 \\
\hline 2015 & $4,043467.8$ & $273,858.0$ & 6.8 & $171,690.9$ & 4.2 \\
\hline $\begin{array}{l}\text { The index of total } \\
\text { growth }(\%)\end{array}$ & 978.8 & 361.4 & & 616.3 & \\
\hline $\begin{array}{l}\text { The average growth } \\
\text { rate }(\%)\end{array}$ & 16.4 & 8.9 & & 12.9 & \\
\hline
\end{tabular}

Sourse: Statistical Office of the Republic of Serbia, Belgrade, Electronical databases, February, 2017

The development of agriculture in the beginning of XXI Century was accelerated by the technical-technological progress and structural changes and use in agro-economy. High developed countries have achieved such level of development that agriculture has been totally supressed (in EU the primary sector has the share of $1.8 \%$ in GDP). However, from previous presentation can notice that the state in agriculture in Serbia is the opposite. Hence, there are low salaries of employees, which don't provide workers to supply themselves and their families with food, and therefore there is no growth of demand for them. They will increase if there comes to the economic growth (according to IMF assessments, a rate of economic growth in the year 2017 will amount 3\%), EP 2017 (64) 2 (805-819) 
and it will affect the increase in salaries, by which will be made conditions for the growth of demand for agricultural products. This process cannot be achieved in a short time period. Besides a bad situation in economy and agriculture, it is the brightest point (branch) in our underdeveloped market economy. There is no doubt, agriculture together with agro-industry, represents a developmental chance for Serbia, which means that its share in the creation of GDP will not be significantly decreased. That is why is necessary to keep the competitiveness of prices in vegetable products, ,increase productivity by the new investments, modernization of agricultural production, more dynamic development of livestock breeding in regard to vegetable production, but also by the reduction of excess employees“" (Savić et al., 2016).

In the text below, we will perceive the dynamic in GDP trends and an income in agriculture through a linear trend (Graph 3 ). We can notice that the trend is adjusted to the phenomenon. That is to say, we have a decreasing trend in GDP, i.e. a coefficient of determination is high $\left(\mathrm{R}^{2}=0.9913\right)$. There is also an increasing trend, i.e. the coefficient of determination is high regarding an income in agriculture $\left(\mathrm{R}^{2}=0.9105\right)$.

Graph 3. Agricultural income and total GDP

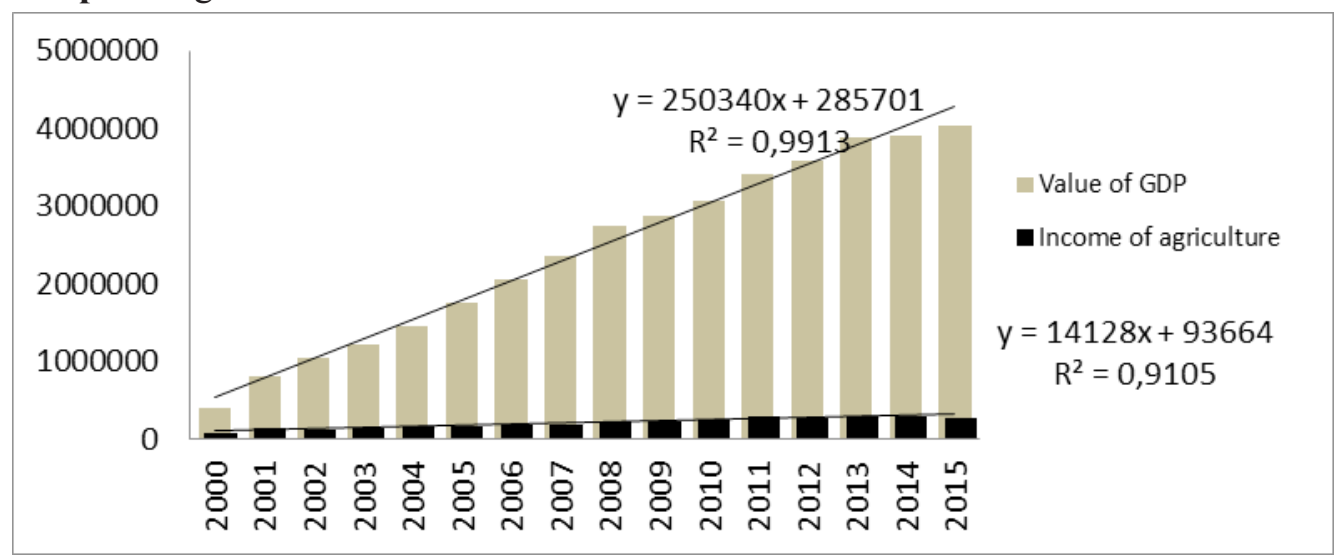

Sourse: Author's calculations based on Table 1.

When it is about the share of income of agriculture in the GDP (Graph 4), the coefficient of determination is lower and amounts $\mathrm{R}^{2}=0.7347$. It means that the linear trend isn't well adjusted to the phenomenon. Likewise, in the share of income of agriculture in the GDP, the linear trend determines the regularity of development - to decrease the share of agriculture in GDP of our country for the period 2000-2015. Hence, the dynamics of trends is increasing in GDP and the income of agriculture, while the share of agriculture in GDP was expressing a declining trend. 
Graph 4. Share of agriculture in GDP

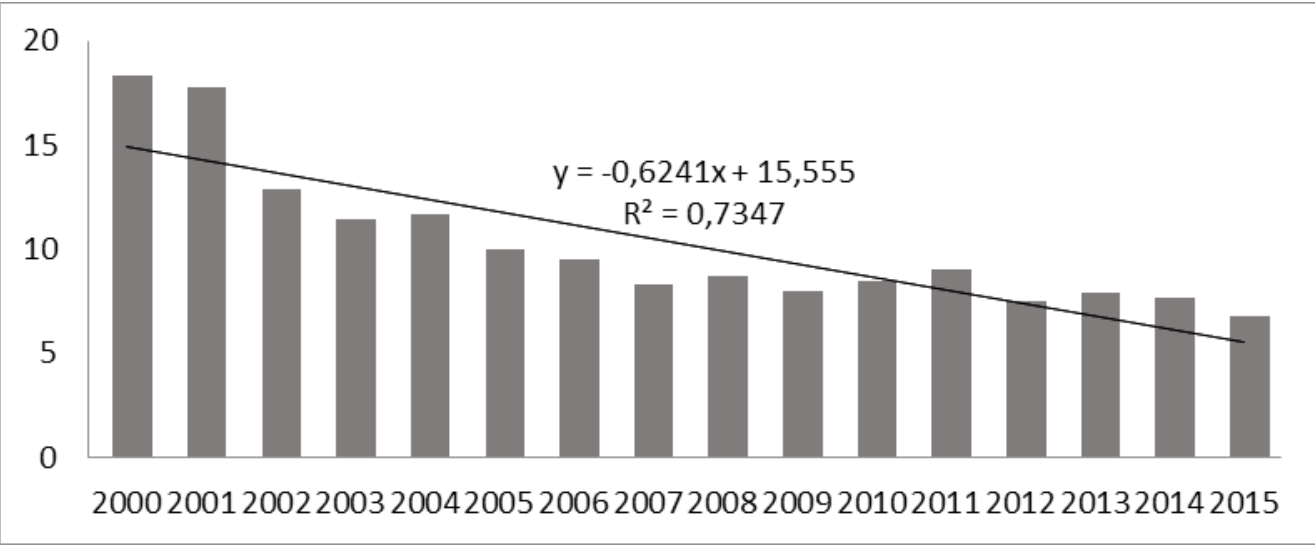

Sourse: Author's calculations based on Table 1

\section{Contribution of agriculture in foreign trade exchange}

For underdeveloped countries is characteristic that, thanks to the foreign trade exchange, achieve profiteering through the export of agricultural products. That is to say, since the year 2005 Serbia has been a net exporter of agricultural-food products and the export of agricultural products has a slightly increasing trend in past years. Taking into consideration that agriculture in all official strategies of Serbian economy development is distinguished as a strategic economic branch, means that an imperative in future must be the increase in export of agricultural products, not only due to agriculture, but because of the rest of economy. Therefore the increase in export requires a complex approach to this problem. This primarily refers to the increase in efficiency of our agriculture, the change of production structure of agricultural production (livestock production $34 \%$ and vegetable production $66 \%$ ) that would go in the direction of approaching to the structure of agricultural production of EU countries (livestock production $70 \%$, and vegetable production $30 \%$ ). Thereby would significantly make conditions for the increase of competitiveness, productivity and new values of our agricultural products on the EU market, where the export of livestock products is unsatisfying. Data from the year 2013 speaks how urgent is to solve the problem in Serbian agriculture. That is to say, "the productivity of our agriculture is better only than agriculture in Poland. Added value per employee in the Serbian agriculture is 30.6 times lower than in Slovenia, and 4.3 times lower than the EU average" (Savić et al., 2016).

The significant increase in share of agricultural-food products in the total export was recorded after the year 2009 (Table 2), so Serbia realizes a significant surplus in the foreign trade exchange of agricultural and food products, which was amounted around a milliard USD in 2010, and in 2011 over a milliard USD. The highest export of agriculturalfood was realised in the year 2014 and was amounted 3.1 milliard USD and was for 1.2 milliard USD higher in regard to the year 2009 (SORS, 2017). 
Table 2. Structure of exports of agriculture and food industry, 2009-2015.

millions US\$

\begin{tabular}{|c|c|c|c|c|c|c|c|}
\hline Year & 2009 & 2010 & 2011 & 2012 & 2013 & 2014 & 2015 \\
\hline Food and live animals & 1509 & 1768 & 2092 & 2095 & 2097 & 2367 & 2088 \\
\hline Live animals & 57 & 67 & 74 & 59 & 47 & 39 & 59 \\
\hline Meat and meat products & 65 & 60 & 59 & 64 & 71 & 147 & 97 \\
\hline Dairy products and birds' eggs & 64 & 69 & 91 & 86 & 83 & 108 & 89 \\
\hline $\begin{array}{l}\text { Fish, crustaceans, molluscs and } \\
\text { their products }\end{array}$ & 5 & 4 & 4 & 4 & 5 & 7 & 6 \\
\hline Cereals and cereal-based products & 477 & 579 & 732 & 835 & 664 & 787 & 640 \\
\hline Vegetables and fruits & 452 & 529 & 658 & 539 & 670 & 748 & 764 \\
\hline Sugar, sugar products and honey & 159 & 216 & 187 & 195 & 208 & 161 & 114 \\
\hline $\begin{array}{l}\text { Coffee, tea, cocoa and their } \\
\text { products }\end{array}$ & 84 & 84 & 85 & 78 & 80 & 87 & 83 \\
\hline $\begin{array}{l}\text { Animal feed (no cereals in the } \\
\text { grain) }\end{array}$ & 62 & 74 & 102 & 132 & 127 & 136 & 110 \\
\hline $\begin{array}{l}\text { Miscellaneous food products and } \\
\text { derivatives }\end{array}$ & 84 & 87 & 100 & 104 & 143 & 147 & 126 \\
\hline Beverages and tobacco & 249 & 232 & 274 & 286 & 320 & 398 & 441 \\
\hline $\begin{array}{l}\text { Alcoholic and non-alcoholic } \\
\text { beverages }\end{array}$ & 193 & 177 & 215 & 213 & 214 & 223 & 189 \\
\hline Tobacco and tobacco products & 56 & 55 & 59 & 73 & 106 & 176 & 251 \\
\hline $\begin{array}{l}\text { Crude materials, inedible, except } \\
\text { fuels }\end{array}$ & 64 & 99 & 137 & 129 & 197 & 157 & 186 \\
\hline leather and fur, raw & 14 & 28 & 37 & 39 & 53 & 44 & 35 \\
\hline Oil seeds and oil fruits & 23 & 42 & 61 & 58 & 102 & 66 & 118 \\
\hline $\begin{array}{l}\text { Raw materials of animal or } \\
\text { vegetable }\end{array}$ & 27 & 29 & 39 & 33 & 42 & 47 & 33 \\
\hline $\begin{array}{l}\text { Animal and vegetable oils, fats } \\
\text { and waxes }\end{array}$ & 135 & 160 & 222 & 215 & 214 & 191 & 195 \\
\hline Animal oils and fats & 2 & 2 & 3 & 3 & 4 & 6 & 2 \\
\hline $\begin{array}{l}\text { Fixed vegetable fats and oils } \\
\text { processed }\end{array}$ & 116 & 138 & 189 & 184 & 178 & 139 & 150 \\
\hline Animal. and vegetable fats, oils & 5 & 5 & 9 & 8 & 7 & 6 & 5 \\
\hline $\begin{array}{l}\text { Other, not specified agricultural } \\
\text { products and foodstuffs }\end{array}$ & 13 & 16 & 21 & 19 & 25 & 40 & 38 \\
\hline $\begin{array}{l}\text { Exports of agriculture and food } \\
\text { products, (mill. US \$ ) }\end{array}$ & 1957 & 2259 & 2724 & 2726 & 2829 & 3113 & 2909 \\
\hline Total exports, (mill. US \$ ) & 8344 & 9794 & 11779 & 11228 & 14610 & 14845 & 13379 \\
\hline $\begin{array}{l}\text { Imports of agriculture and food } \\
\text { products, (mill. US \$ ) }\end{array}$ & 1079 & 1287 & 1513 & 1595 & 1748 & 1883 & 1711 \\
\hline $\begin{array}{l}\text { The balance of foreign trade in } \\
\text { agriculture }\end{array}$ & 878 & 972 & 1212 & 1131 & 1081 & 1230 & 1198 \\
\hline $\begin{array}{l}\text { Share of agriculture and food } \\
\text { products in exports (\%) }\end{array}$ & 23,5 & 23,1 & 23,1 & 24,3 & 19,4 & 21,0 & 21,7 \\
\hline
\end{tabular}

Sourse: Statistical Office of the Republic of Serbia, Belgrade, Electrical databases, February, 2017 
In Table 2 we can notice the decrease in export value of agricultural-food products in 2015 to 2.9 milliard USD. When it is about the export structure in 2015, we can notice that food made $71.8 \%$ of agro-food products export, beverages and tobacco $15.1 \%$, inedible crude material, except fuel 6.4\%, and animal and vegetable oils and fats $7.2 \%$.

The share of agriculture in total export is high and was amounted $21.7 \%$ in 2015 and was pointed out to both on the comparative advantages of agriculture and food production in export, and on the slow structural changes in a state's economy. The analysis also points out that the share of agro-food products export in the year 2015 in the total export was $7.8 \%$. It practically means that every fifth dollar in 2015 was earned by the export of food, and that for every eleventh dollar in the total Serbian export was responsible the import of agro-food products.

If we could recognize the regional distribution of agricultural and food industry export, we could notice that export in EU-28, the CEFTA members and the Russian Federation in the year 2015 was amounted around $89.3 \%$ of this sector export (SORS, 2017). In the year 2015 , there was found the EU market for most of agro-food products $-48.3 \%$, and then on the market of CEFTA members $31.7 \%$ and in the Russian Federation, around $9.3 \%$ of the total export of agricultural and food products. Otherwise, there are expected intensifying exports on the Russian market. Nowadays is especially expressed the demand for pork and dairy products, as a result of the suspension of imports from the EU, due to the Ukrainian crisis.

„However, although the quality of products and a price aren't debatable for the Serbian exporters, numerous problems occur in the field of a higher export of agro-food products from Serbia to Russia. Some of these problems are: 1) low capacities of production and the poor export supply from Serbia, 2) a large number of sub-distributors and a high margin (which significantly increases the price of goods at retail), 3) administrative sluggishness in solving the foreign trade issues and the issues of veterinary, phytosanitary and other conditions of export, 4) variable and numerous requests which Russia sets for the Serbian exporters" (Cvijanović et al., 2013b).

Graph 5. Linear trend of exports

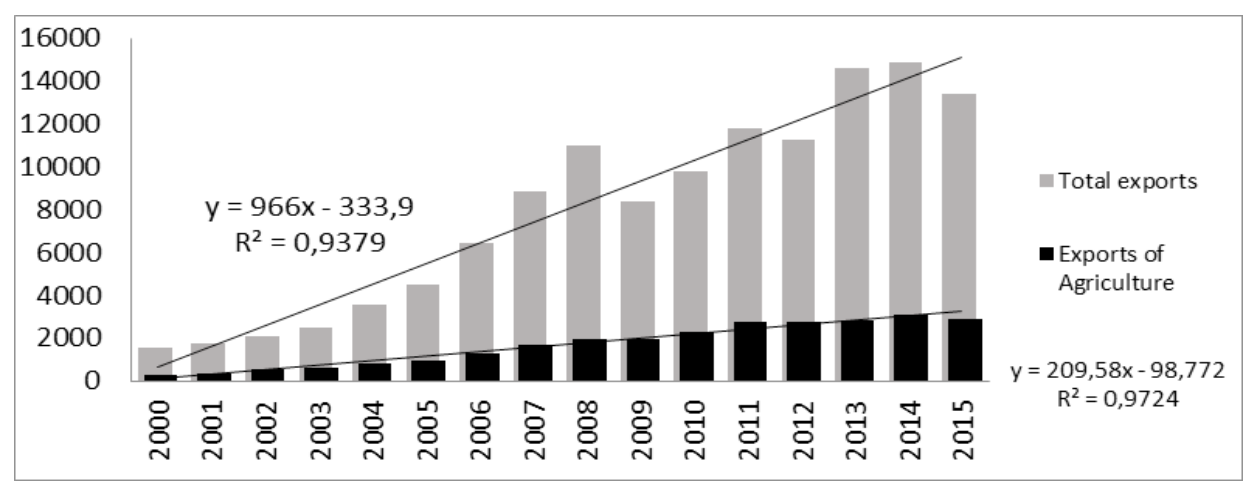

Sourse: Author's calculations based on Table 2

EP 2017 (64) 2 (805-819) 
There is no doubt that the state on the world market of agricultural products, the trade liberalisation with the EU, CEFTA and Russian Federation, as well as the results in the field of agricultural sector restructuring and the increase in competitiveness were made conditions for the Serbian agriculture export in the previous and in the beginning of the current decade. Surely the results of export will depend on the possibility of agricultural sector to satisfy demand, as regarding quantity, as well as the quality of products. In that sense, it is necessary to respect the established standards on safety and quality of products - GLOBALGAP, HACCP, Halal, Kosher... (Veljković, Ševarlić, 2010).

As we can notice in the Graph 5, the given trend explains most of the variation, i.e. is well adjusted to the phenomenon. That is to say, the dynamics of total export/import of agro-food products trend is shown through a linear trend. There can be noticed that the increasing trends are present in total export and import of agro-food products, i.e. with a high coefficient of determination. In the total export is $\mathrm{R}^{2}=0.9379$, while in the export of agro-food products, the coefficient of determination is higher and amounts $\mathrm{R}^{2}=0.9724$. When it is about the dynamics of total imports trend, we can ascertain that there is poor anticipation of future trends (Graph 6). It just shows the coefficient of determination. Specifically, in total import the coefficient of determination amounts $\mathrm{R}^{2}=0.7819$, while in the import of agro-food products the coefficient of determination is high and amounts $\mathrm{R}^{2}=0.9606$. Based on these data, we can conclude that the increase in total export of the Republic of Serbia affects significantly on the export of agro-food products.

Graph 6. Linear trend od imports

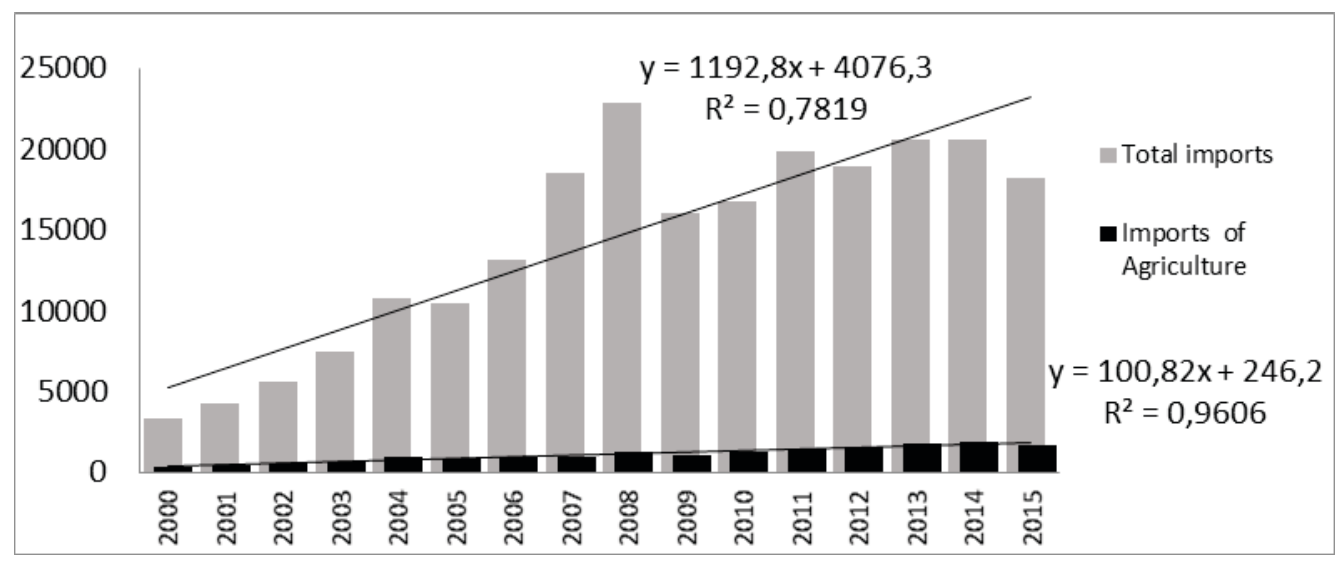

Sourse: Author's calculations based on Tabel 2.

\section{Conclusion}

1. It was determined, by an analysis of the rural population share in total population that the share of rural population (absolutely and relatively) was decreasing in total population. The research showed that the share of total rural population in total population in Serbia in the period 2002-2011 was decreased from $10.9 \%$ to $6.8 \%$. It points out to a fact that the process of deagrarization in Serbia is still present and develops uncontrolled; so 
many villages were practically destroyed (abandoned). Besides, 1.034 villages have less than 100 inhabitants. Likewise, Serbia has unsatisfying age structure of work force in agriculture. The share of holders of holdings older than 50 years of age was $44.32 \%$ in the year 2002, and in 2012 was increased to $63.2 \%$. The share of agriculture in total employment in Serbia was relatively high and was amounted $21.8 \%$ in the period from 2004 to 2015, and was mostly the consequence of privatization, seasonal and temporary jobs, decay of industry, as well as a low inflow of foreign direct investments.

2. The contribution of agriculture in economic development mostly determines through the share of this economic branch in the creation of GDP. Researches have shown that the share of agriculture in GDP in the analysed period (2000-2015) is in accordance with the developmental principles. That is to say, the share of our agriculture in GDP was decreased from $18.3 \%$ in the year 2000 to $6.8 \%$ in 2015, while the share of agro-industry (food products, beverages and tobacco) was decreased from $6.7 \%$ in 2000 to $4.2 \%$ in 2015 .

3. Since the year 2005, Serbia has a consistently positive balance (surplus) of the agro-food products exchange. The share of agro-food products in total export of Serbia (2005-2015) was relatively high and stabile (except in 2008, 17.8\%) and was settled on about $22 \%$, while import was settled on about $8 \%$. The researches were also shown that practically every fifth dollar in 2015 was earned by the food export, and every eleventh was earned by the total Serbian import of agro-food products. It points out that agriculture is a very significant factor in the foreign trade exchange of the country.

\section{Literature}

1. Bogdanov, N., Babović, M. (2014): Radna snaga i aktivnosti poljoprivrednih gazdinstava, RZS, Belgrade, Serbia.

2. Cvijanović, D., Mihailović, B., Paraušić, V. (2013a): Analiza performansi primarne poljoprivredne proizvodnje i prehrambene industrije Srbije, Agroznanje, Vol. 14, No. 1, pp. 77-85, Univerzitet u Banja Luci, Poljoprivredni fakultet, Banja Luka, Republika Srpska.

3. Cvijanović, D., Paraušić, V., Mihailović, B.(2013b): Izvozni potencijali plasmana poljoprivredno-prehrambenih proizvoda iz $R$. Srbije na tržište Ruske federacije, Zbornik radova - Iskustva i perspektive ekonomske saradnje Srbije i Rusije, Međunarodni naučni skup IPES-SR 2013, ISBN 978-86-80127-69-9, p.p. 319-332, Univerzitet u Prištini, Ekonomski fakultet, Kosovska Mitrovica.

4. CEP - Centar za evropsku politiku (2017), Poljoprivreda u Srbiji - Šta može očekivati u procesima pristupanja EU?, from htpp://www.europearpolicy.org/ documentacioni-centar/cep-pogled/418-poljoprivreda-u-Srbiji-šta-možemoočekivati-u-procesu-pristupanja-eu.html (15.01.2017.)

5. Maksimović, G., Pejanović, R., Negovan, Z. (2013): Ekonomika poljoprivrede, ISB 978-86-80737-35-5, Univerzitet u Kosovskoj Mitrovici, Poljoprivredni fakultet, Lešak. 
6. Milanović, M. (2002): Agrokompleks u ekonomskoj strukturi SR Jugoslavije značaj i promene 1955-2000, Ekonomika poljoprivrede, Vol. 49, No. 3-4, pp. 111129, Društvo agrarnih ekonomista Jugoslavije et al., Belgrade, Serbia.

7. Mitrović, S. (2016a): Doprinos poljoprivrede u razvoju Srbije (doktorska disertacija), Poljoprivredni fakultet, Univerzitet u Prištini, Lešak.

8. Mitrović, S. (2016b): Pravednije merenje društvenog bogastva radi održivog razvoja, Tematski zbornik radova - Ljudska prava između ideala i izazova sadašnjosti (Naučni skup sa međunarodnim učešćem), ISBN 978-86-6083-042-7, p.p. 247-259, Univerzitet u Prištini, Pravni fakultet, Kosovska Mitrovica.

9. Ministarstvo poljoprivrede, šumarstva i vodoprivrede Republike Srbije (MPZŽS) (2014): Strategija poljoprivrede i ruralnog razvoja Republike Srbije (2014-2024), Belgrade, Serbia.

10.Pejanović, R. (2008): Investicije u poljoprivredi Republike Srbije, Ekonomika poljoprivrede, Vol. LV, No. 1, pp. 9-19, Naučno društvo agrarnih ekonomista Balkana et al.,Belgrade, Serbia.

11.Praća, N., Paspalj, M., Paspalj, D. (2017): Ekonomska analiza uticaja savremene poljoprivrede na održivi razvoj, Oditor, Belgrade, Serbia, Vol. 3, No. 1, pp. 37-51.

12.Republički zavod za statistiku, RZS (2012): Popis stanovništva, domaćinstva $i$ stanova 2011. godine, Belgrade, Serbia.

13. Republički zavod za statistiku(RZS) (2013): Popis poljoprivrede 2012, Poljoprivreda u Republici Srbiji, Belgrade, Serbia.

14.Republički zavod za statistiku (RZS) (2015): Ekonomski računi poljoprivrede u Republici Srbiji, 2007-2014, Belgrade, Serbia.

15.Republički zavod za statistiku (RZS) (februar, 2017): Elektronska baza podataka, Belgrade, Serbia.

16.Savić, Lj., Bošković, G., Mićić, V. (2016): Serbian agroindustry - Potentials and perspectives, Economies of agriculture, Vol. LXIII, No. 1, p.p. 107-122, The Balkan Scientific Association of Agrarian Economists et, al., Belgrade, Serbia.

17.Stevanović, S., Đorović, M. (2009): Komparativna analiza rezultata tranzicionih procesa u agroprivredi Srbije i nekih zemalja CIE, Tematski zbornik: Poljoprivreda i ruralna područja Srbije, pp. 51-69, DAES, Belgrade, Serbia.

18.Stipetić, V. (1987): Poljoprivreda i privredni razvoj, Informator, Zagreb, Hrvatska.

19. Tomić, D., Vlahović, B., Radivojević, V. (2002): Osnovne performanse jugoslovenskog agrara, Ekonomika poljoprivrede, Vol. 49, No. 1-2, pp. 3-11, DAEJ, Belgrade, Serbia.

20.Veljković, B., Ševarlić, M. (2010): Proizvodno-izvozne mogućnosti Srbije na Evropskom tržištu zdravstvene bezbedne hrane, Tematski zbornik, Agroprivreda Srbije i evropske integracije - (ne)prilagođenost obostranoj primeni Prelaznog trgovinskog sporazuma, ISBN, 978-86-86087-19-5, p.p. 115-138, DAES, Belgrade, Serbia. 


\title{
DOPRINOS POLJOPRIVREDE U RAZVOJU SRBIJE
}

\author{
Slavka Mitrović5 ${ }^{5}$ Aleksandra Mitrović ${ }^{6}$, Maja Cogoljevićc ${ }^{7}$
}

\section{Apstrakt}

Republika Srbija ima značajne resurse za razvoj poljoprivrede (prirodni, naučni $i$ stručni). Međutim, poljoprivreda ne ostvaruje rezultate adekvatne uslovima koji za nju postoje i koji se od njih očekuju.

Cilj istraživanja u ovom radu je sagledavanje doprinosa poljoprivrede u razvoju Srbije. Doprinos poljoprivrede razmatran je analizom sledećih pokazatelja: 1. učešće poljoprivrednog u ukupnom stanovništvu i aktivnog poljoprivrednog stanovništva u ukupnoj radnoj snazi, 2. učešće poljoprivrede u formiranju bruto domaćeg proizvoda (BDP) i 3. doprinos poljoprivrede i agroindustrije u spoljnotrgovinskoj razmeni. Analiza navedenih pokazatelja ukazuje da naša strategija razvoja mora se zasnivati na povećanju izvoza poljoprivredno-prehrambenih proizvoda (intezivnoj proizvodnji), i izmeni proizvodne strukture u skladu sa platežnom tražnjom (posebno za tražnjom ekološki zdravom hranom) $i$ čiji bi stepen finalizacije bio veći, kako bi se povećala konkurentnost i nova vrednost. U radu su korišćeni publikovani podaci RZS, zatim, rezultati istraživanja nekih autora iz ove problematike, kao i rezultati drugih istraživanja autora ovog rada. Istraživački period je od 2000. do 2015. godine. Kod analize doprinosa (performansi) poljoprivrede korišćene su sistemska i komparativna analiza, kao i standardni statističko-matematički instrumentarijum: prosečne vrednosti, stope promene, koeficijent determinacije. U radu su prezentirani i linearni trendovi kretanja $B D P i$ dohotka poljoprivrede $i$ učešće poljoprivrede u BDP, kao i trendovi izvoza $i$ uvoza ukupne privrede i poljoprivrede.

Ključne reči: poljoprivreda, poljoprivredno stanovništvo, bruto domaći proizvod (BDP), spoljnotrgovinska razmena, konkurentnost.

5 Dr Slavka Mitrović, Asistent,Univerzitet u Prištini, Poljoprivredni fakultet, 38219 Lešak, Telefon: +3812888261, E-mail: slavka.mitrovic@pr.ac.rs.

6 Master Aleksandra Mitrović, Profesor, Šumarska škola Kraljevo, Karađorđeva Ulica br. 262, 36000 Kraljevo, Telefon: +38136352235, E-mail: aleksandramitrovic754@gmail.com

7 Docent, dr Maja Cogoljević, Visoka škola za poslovnu ekonomiju i preduzetništvo, Ulica Vojvode Vlahovića br. 35b, Beograd, Srbija, Telefon: +381 6310211 28, E-mail: maja.cogoljevic@vspep.edu.rs.

EP 2017 (64) 2 (805-819) 